\title{
Genetic sequence stratigraphy on the basis of ichnology for the Middle Jurassic basin margin succession of Chorar Island (eastern Kachchh Basin, western India)
}

\author{
Jehova L. Darngawn, Satish J. Patel ${ }^{*}$, Jaquilin K. Joseph, Apuva D. Shitole \\ Department of Geology, The M.S. University of Baroda, Vadodara, Gujarat, India \\ *corresponding author, e-mail: sjpgeology@gmail.com
}

\begin{abstract}
Synrift basin margin successions are greatly influenced by eustatic sea level changes, tectonics and accommodation space filled in by sediments. The Middle Jurassic (Bajocian-Callovian) of Chorar Island (western India) comprises a 109-m-thick synrift basin margin succession of clastic, non-clastic and mixed siliciclastic-carbonate rocks which are here analysed and categorised into nine lithofacies. The succession is bioturbated to varying intensities; 16 identified ichnogenera can be assigned to environmentally related groups of five trace fossil assemblages, which include Gyrochorte, Hillichnus, Rhizocorallium, Skolithos and Thalassinoides. These ichnoassemblages document the Skolithos and Cruziana Ichnofacies which marks a change in energy conditions, sedimentation dispersal patterns and bathymetry in a shallow-marine environment. The Bajocian-Callovian succession is further analysed on the basis of sedimentological and ichnological data that show two genetic sequences consisting of Transgressive Systems Tract and Highstand Systems Tract bounded by Maximum Flooding Surface. The synrift basin margin succession of the Middle Jurassic of Chorar Island shows cyclicity in deposition; the Bajocian-Bathonian succession represents progradational to retrogradational coastlines, while the Callovian succession documents an aggrading progradational coastline.
\end{abstract}

Key words: Synrift basin, Bajocian-Callovian, lithofacies, ichnofacies, base level

\section{Introduction}

The accommodation history of rift basins is strongly linked to their mechanical subsidence regime with episodic pulses of extension that create space for sediment accumulation at very fast rates (Martins-Neto \& Catuneanu, 2009). A sequence-stratigraphical model for rift basin defines the dominant stratigraphical patterns that are commonly encountered in tectonic settings and provides a framework for understanding the process-response relationship between controls on accommodation and the resultant stratigraphical architecture of rift basins (Martins-Neto \& Catuneanu, 2009).
The Kachchh Basin in western India is a peri-continental embayment in an east-west-trending graben between the Nagar Parkar-Allah bund and North Kathiawar faults, which is filled by synrift sedimentary rocks within two major cycles: a transgression with the opening of the rift and a regression with rift failure during the Late Cretaceous (Biswas, 1999). The Jurassic strata formed in a shallow-marine, inner-shelf environment during transgression (Biswas, 1999), where normal faults controlled the creation of accommodation space for syntectonic deposition in a rift basin (Biswas, 1983, 2005).

The basin margin successions have been studied by various workers for their lithostratigraphy 
(Biswas, 1971, 1977, 2016; Fürsich et al., 2001) and structure and tectonics (Biswas, 1983, 2005). Several workers have also studied the palaeoenvironment of these successions using different approaches such as palaeontology (Guha, 1977; Khosla et al., 2003), ichnology (Howard \& Singh, 1985; Shringarpure, 1986; Kulkarni \& Ghare, 1991; Fürsich, 1998; Patel et al., 2008, 2009, 2014; Joseph et al., 2012a; Darngawn et al., 2018) and sedimentology (Patel et al., 2010; Joseph et al., 2012b). Attempts have also been made to analyse the succession on the basis of sequence stratigraphy (Patel et al., 2010, 2013; Patel \& Joseph, 2012).

The Mesozoic succession of the Kachchh Basin consists mainly of rift-filled deposits exposed in isolated patches and ranging in age from Aalenian to Albian (Biswas, 2016). Chorar Island is an isolated subbasin along the strike of the Island Belt Fault, comprising Bajocian to Callovian deposits. The present paper is focused mainly on an analysis of sedimentological and ichnological data for the synrift succession of Chorar Island (eastern Kachchh Basin), in order to deduce the genetic cycles and also discuss the implications of global eustatic sea level during the Bajocian to Callovian stages. The sedimentological and ichnological data will throw light on the dominant process and the process response of Middle Jurassic strata with respect to global sea level within the subbasin.

\section{Geological setting}

Chorar Island lies in the easternmost part of the island belt zone of the Kachchh Basin between lati-

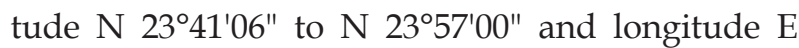
$71^{\circ} 00^{\prime} 55^{\prime \prime}$ to $\mathrm{E} 71^{\circ} 18^{\prime} 36^{\prime \prime}$, in the Patan District of Gujarat (Fig. 1) along the strike of the Island Belt fault.
The east-west-trending Island Belt Fault (IBF) forms a series of horsts and grabens in the northern part of the Kachchh Basin, consisting of four major uplifts in the form of the Patcham, Khadir, Bela and Chorar islands (Biswas, 2005). This uplift exposes the basin margin synrift succession of Middle Jurassic age recorded here. The succession in Chorar Island is characterised by distinct and unique facies associations that have recently been described with detailed data on stratigraphy and sedimentology by Patel et al. (2018) and on ichnology by Darngawn et al. (2018).

Chorar Island, on the eastern flank of the basin, contains strata that range in age from the Bajocian to Callovian and comprises the Khadir and Gadhada formations. A shale-dominated sequence of the Hadibhadang Shale Member is exposed at the base of the succession and is overlain by a mixed siliciclastic-carbonate-dominated Hadibhadang Sandstone Member of the Khadir Formation. The top of the Hadibhadang Sandstone Member is characterised by coralline limestone which is equivalent to the Raimalro Limestone Member of the Goradongar Formation (Biswas, 2016) and the Patcham Formation of Fürsich et al. (2013). The whole succession is capped by the Ratanpur Sandstone Member of the Gadhada Formation (Biswas, 2016; Patel et al., 2018) which consists of thickly bedded, ferruginous sandstone, with cross-bedded white sandstone and thinly bedded mudstone and shales.

\section{Sedimentology and ichnology}

The Middle Jurassic succession (Fig. 5) of Chorar Island is exposed in discontinuous and isolated patches and comprises a 109-m-thick succession of the Khadir Formation (Hadibhadang Shale and Hadibhadang Sandstone members) and the Gadha-

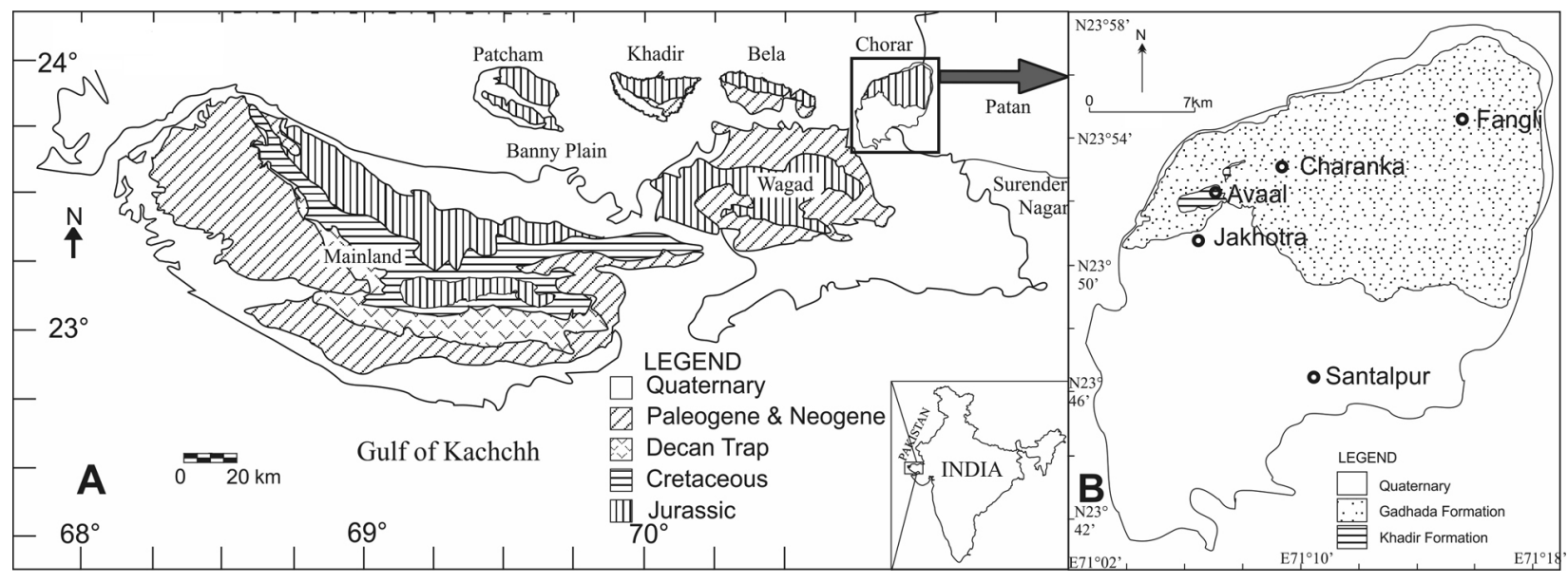

Fig. 1. Location and geological map of Chorar Island 
da Formation (Ratanpur Sandstone Member). Our sedimentological analysis has demonstrated nine lithofacies, viz., a ferruginous sandstone, a cross-bedded white sandstone, an allochemic sandstone, mudstone, a coralline limestone, a sandy allochemic limestone, a micritic sandstone, a sandy micrite and a shale facies (Patel et al., 2018). The ferruginous sandstone, cross-bedded white sandstone and micritic sandstone facies are moderately bioturbated, while the sandy allochemic limestone facies is relatively more bioturbated and yields sixteen identifiable ichnogenera (Arenicolites, Asterosoma, Curvolithus, Didymaulichnus, Diplocraterion, Gyrochorte, Halopoa, Hillichnus, Lockeia, Megagrapton, Palaeophycus, Planolites, Protovirgularia, Rhizocorallium, Skolithos and Thalassinoides) (Darngawn et al., 2018), which document a moderate diversity in behaviours (i.e., dwelling, feeding and crawling). The characteristic set of an environmentally related group of trace fossils also revealed five ichnoassemblages representing the Skolithos (Skolithos assemblage) and Cruziana (Gyrochorte, Hillichnus, Rhizocorallium and Thalassinoides assemblages) ichnofacies. Each ichnoassemblage is characterised by a particular suite of trace fossils that reflect unique hydrodynamic conditions, substrate consistency and bathymetry (Joseph et al., 2012a) during deposition.

The micritic sandstone (siliciclastic: $65-70$ per cent, Rx: 5-10 per cent, Micrite: 20 per cent) attains a thickness of $+13.3 \mathrm{~m}$, is grey to brownish in colour and characterised by cross-bedding and ripple marks, as has been observed in the Hadibhadang Sandstone and Hadibhadang Shale members. The Micritic Sandstone of the Hadibhadang Sandstone Member yields Halopoa (Fig. 2A), Palaeophycus (Fig. 2B), Rhizocorallium, Thalassinoides (Fig. 2C) that form the Thalassinoides ichnoassemblage.

The sandy allochemic limestone, 1-2 m thick, is a bright yellow-coloured mixed siliciclastic-carbonate rock, as observed in the Hadibhadang Sandstone
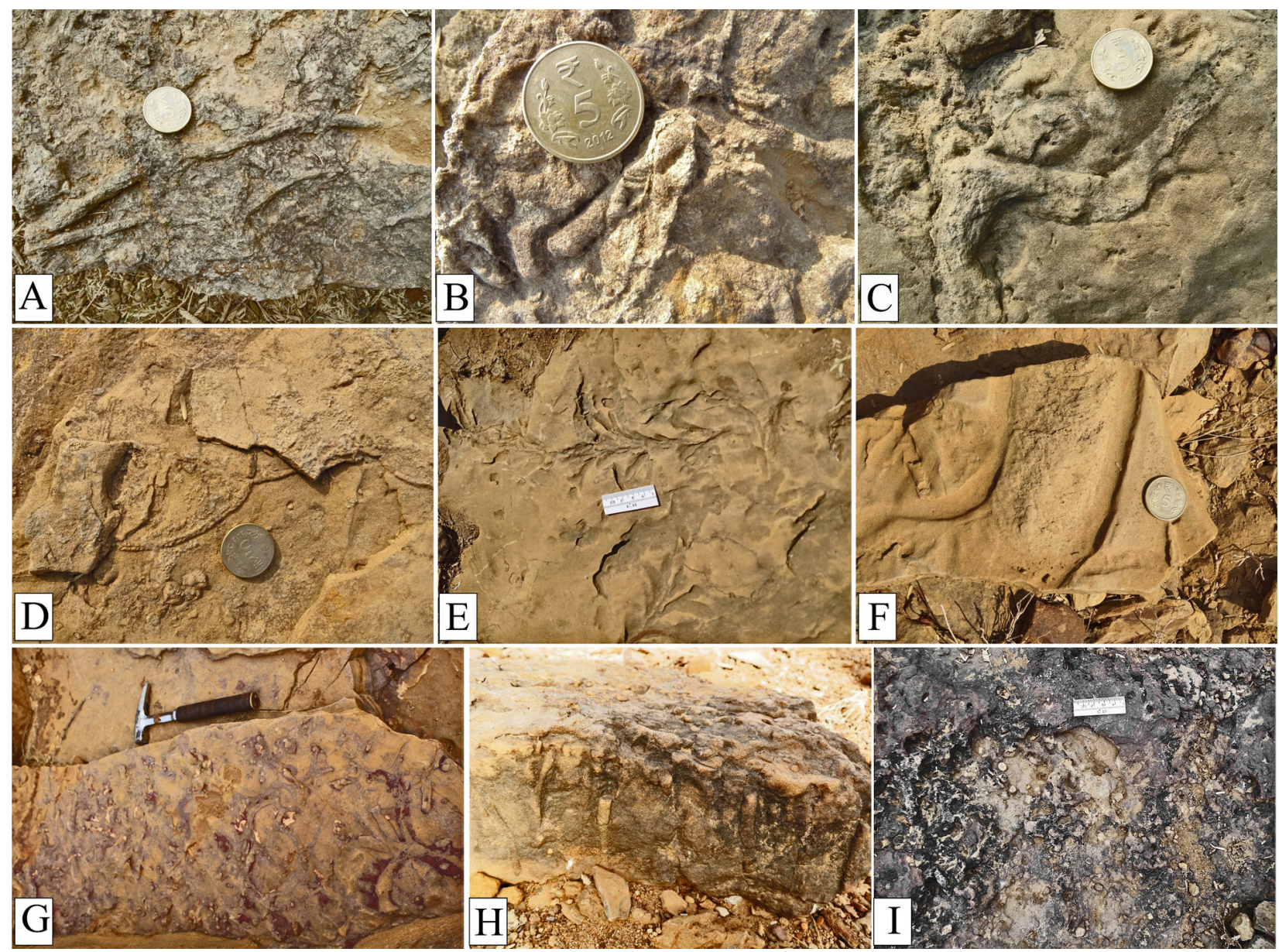

Fig. 2. A - Halopoa; B - Palaeophycus; C - Thalassinoides of the micritic sandstone facies of the Hadibhadang Sandstone Member (top view); D - Gyrochorte; E - Hillichnus (scale bar equals $50 \mathrm{~mm}$ ); F - Rhizocorallium; G - Thalassinoides at sediment-sediment interface in the sandy allochemic limestone facies of the Hadibhadang Sandstone Member (top view); H - Skolithos in the cross-bedded white sandstone facies (side view); I - Skolithos in the ferruginous sandstone facies of the Ratanpur Sandstone Member (top view; scale bar equals $50 \mathrm{~mm}$ ) 
Member of the Khadir Formation. The carbonate component (allochems: 35-40 per cent, micrite: 1520 per cent) exceeds the siliciclastic (35-40 per cent) component. This unit is highly fossiliferous and yields bivalves (Trigonia, Corbula and Gervinella), algae, echinoid spines, foraminifera and brachiopods and is also bioturbated in nature. This facies recurs in time and is preferentially bioturbated by a variable number and types of organisms that produced Arenicolites, Asterosoma, Didymaulichnus, Gyrochorte (Fig. 2D), Halopoa, Hillichnus (Fig. 2E), Lockeia, Megagrapton, Palaeophycus, Planolites, Protovirgularia, Rhizocorallium (Fig. 2F) and Thalassinoides (Fig. 2G). The distinct occurrence of trace fossils in different bands allows the distinction of four assemblages, namely: Hillichnus, Rhizocorallium, Gyrochorte and Thalassinoides. The Hillichnus assemblage consists mainly of Hillichnus and Protovirgularia; the predominance of Hillichnus, illustrating a complex deposit-feeding behaviour produced by tellinoid bivalves (Bromley et al., 2003) and crawling structures such as Protovirgularia made by bivalves (Carmona et al., 2010). The Rhizocorallium assemblage comprises mainly Arenicolites, Asterosoma, Didymaulichnus, Lockeia and Rhizocorallium, documenting a predominance of deposit feeders such as polychaetes (Chamberlain, 1977), worms (Pemberton, 2001), gastropods (Hakes, 1985), bivalves (Seilacher, 1953) and crustaceans (Seilacher, 2007), respectively; these indicate well-oxygenated, nutrient-rich soft substrates. The Gyrochorte assemblage encompasses mainly dwelling structures of the Arenicolites and Palaeophycus (Osgood, 1970) and feeding structures such as Gyrochorte, Megagrapton and Planolites, made by worm-like producers (de Gibert \& Benner, 2002; Knaust, 2013) at the sediment-sediment and sediment-water interface in oxygenated sediments. The Thalassinoides assemblage consists of Rhizocorallium, Halopoa and Palaeophycus, with T. horizontalis and T. paradoxicus; Thalassinoides is frequently related to oxygenated settings (Savrda \& Bottjer, 1986) and is produced by decapod crustaceans (Myrow, 1995). The predominance of deposit feeders indicates that the sandy allochemic limestone was a well-oxygenated and nutrient-rich substrate (Bromley \& Frey, 1974; Kern \& Warme, 1974).

The allochemic sandstone facies (Ratanpur Sandstone Member) is light brown to dirty yellow in colour, with bed thicknesses of $0.5 \mathrm{~m}$, comprising of 60 per cent siliciclastic and 40 per cent of carbonate material (allochems, 30 per cent and micrite 10 per cent).

The Mudstone facies (Dunham, 1962) is also recognised in the Ratanpur Sandstone Member and is characterised by greyish to brown-coloured, with thin intercalations of shales. It shows less than 5 per cent of allochems (micritised bioclasts).
The Coralline limestone facies of the Hadibhadang Sandstone Member of the Khadir Formation is grey to dirty yellow in colour and attains a maximum thickness of about $2 \mathrm{~m}$. It yields bivalves and large corals which are diagenetically modified and form large calcite crystals, having lost their internal structures. Siliciclastic components constitute about 5-10 per cent of quartz grains which are fine grained, angular and poorly sorted, indicating negligible clastic influx.

The Sandy micrite facies (siliciclastic: $30-40$ per cent, allochems: 10-20 per cent, micrite: 30-40 per cent) is observed in the Hadibhadang Sandstone Member of the Khadir Formation, characterised by blackish coloured, cross-bedded and planar, laminated intercalated with shales. The shale is characterised by a grey colour and is gypseous, occurring as intercalations in the Ratanpur Sandstone, Hadibhadang Sandstone and Hadibhadang Shale members.

The cross-bedded white sandstone and ferruginous sandstone facies are observed in the Ratanpur Sandstone Member of the Gadhada Formation. The former facies is friable, off-white to yellowish in colour and characterised by cross-bedding, pinching towards the western side of the dome. It shows an increase in calcareous matrix and hence represents a micritic sandstone facies. The cross-bedded white sandstone facies is also bioturbated in nature and yield trace fossil genera such as Skolithos, Planolites and Thalassinoides, representing the Skolithos assemblage. The ferruginous sandstone facies is dark red to brownish in colour, characterised by different types of ripple marks and cross bedding and containing body fossils of bivalves and gastropods, as well as fossilwood. It is moderately bioturbated and yields ichnogenera such as Arenicolites, Diplocraterion, Palaeophycus and Skolithos (Fig. 2H), representing the Skolithos assemblage. This assemblage is dominated by vertical dwelling burrows of opportunistic suspension feeders which were made in unconsolidated, poorly sorted, shifting-substrate sediments in high-energy settings (Seilacher, 1967; Pemberton \& MacEachern, 1995).

The Sandy allochemic limestone and micritic sandstone facies of the Hadibhadang Sandstone Member of the Khadir Formation are dominated by cylindrical, branched to unbranched, large-sized, horizontal endichnial/hypichnial structures such as Asterosoma, Curvolithus, Didymaulichnus, Gyrochorte, Halopoa, Lockeia, Planolites, Palaeophycus, Protovirgularia, Rhizocorallium and Thalassinoides. The T-shaped or curved Y-shaped, branched Thalassinoides is considered a typical member of the Cruziana Ichnofacies (Seilacher, 1967), colonising un- 
der reduced energy conditions in shallow-marine environments. The Cruziana Ichnofacies indicates low to moderate energy conditions and unconsolidated, poorly sorted, soft substrates and plenty of organic detritus in shallow-water marine settings (Pemberton et al., 2001). The ferruginous sandstone facies and cross-bedded white sandstone facies contain ichnogenera such as Arenicolites, Diplocraterion, Planolites and Skolithos (Fig. 2I); these are typical members of the Skolithos Ichnofacies. The fine- to coarse-grained clastic sedimentary rocks, the presence of cross-bedding and the predominant occurrence of vertical burrows indicates unconsolidated, poorly sorted, moderate to high wave and current energy conditions and shifting substrates that were exploited by opportunistic animals in middle shoreface environments (Pemberton et al., 2001).

\section{Sequence stratigraphy}

A model-dependent workflow has been considered in order to assess the relatively conformable succession of Chorar Island. The genetic sequence-stratigraphical model (Galloway, 1989) is considered with maximum flooding surfaces (MFS) as sequence boundaries. This model is independent of subaerial unconformity and recognises the importance of separating forced regressive, normal regressive (lowstand and highstand) and transgressive deposits as distinct genetic units (Catuneanu et al., 2009). The Chorar Island succession lacks Lowstand Systems Tract (LST) and shows retrogradation with flooding surface in Transgressive Systems Tract (TST), overlain by a progradational Highstand Systems Tract (HST), suggesting a typical rift sequence rather than sequence developed in a tectonically stable basin (Martins-Neto \& Catuneanu, 2009).

\subsection{Genetic sequence stratigraphy}

The Middle Jurassic synrift succession of Chorar Island shows a major base level rise with a minor fall at the end of the Bajocian. It comprises one major sequence of approximately 6 myr, of $2^{\text {nd }}$ order hierarchy, which is further subdivided into two cycles of $3^{\text {rd }}$ order genetic sequence of 3 myr each (Vail et al., 1991; Catuneanu, 2006) separated by Flooding Surface (FS) at the end of the Bathonian. It comprises TST-I and HST-II, where LST-I is absent due to a lack of exposure in Chorar Island. However, LST has been observed in the neighbouring Khadir Island along the strike of the Island Belt Fault where the succession is characterised by polymictic conglomerate deposits of an alluvial fan environment (Biswas, 1993).

\subsubsection{Trangressive Systems Tract (TST) - I}

The TST-I, observed in the Hadibhadang Shale and Hadibhadang Sandstone members of the Khadir Formation, is represented by a thick intercalated sequence of shale with mixed siliciclastic-carbonate sedimentary rocks. The succession shows a gradual base level rise with a minor fluctuation at the end of Bajocian, represented by a $\sim 23$-m-thick argillaceous shale (Fig.3A) succession interrupted by cross-bedded micritic sandstone (Fig. 3B) in the Hadibhadang Shale Member. A further rise in the base level during the Bathonian resulted in deposition of a 31-m-thick intercalated sequence of mixed siliciclastic-carbonate sediments which include sandy allochemic limestone, micritic sandstone and sandy micrite with shales and coralline limestone at the top of the Hadibhadang Sandstone Member.

The thick argillaceous shales overlain by micritic sandstone represent a gradual increase in the base level, interrupted by a short-term decrease in local accommodation space with a change in hydrodynamic conditions which allowed deposition of coarse-grained micritic sandstone towards the end of the Bajocian. Haq et al. (1988) and Ruban (2015) also depicted the worldwide gradual transgression during the Bajocian, with short-term changes as regression. The intercalated sequence of mixed siliciclastic-carbonate sediments indicates an increase in carbonate content. The carbonate precipitation and secretion by in-situ organisms (coral) during the Bathonian marks an increase in accommodation space which is also reflected in bioturbation patterns.

The sandy allochemic limestone facies, which overlies the micritic sandstone facies, is intensely bioturbated by Hillichnus (Fig. 3C). This facies recurs with time and is preferentially bioturbated within the systems tract with diverse trace fossil types of Rhizocorallium, Gyrochorte and Thalassinoides assemblages of the Cruziana Ichnofacies (Seilacher, 1967). The presence of Hillichnus in sandy allochemic sandstone indicates a shallow-marine environment (Ekdale \& Ekdale, 2018), while the Rhizocorallium assemblage represents a shoreface to deeper marine environment (Worsley \& Mørk, 2001). The Gyrochorte assemblage of rippled sandy allochemic limestone facies (Fig. 3D) represents the Cruziana Ichnofacies (Seilacher, 1967). It is also developed in the rippled, mixed carbonate-siliciclastic grainstones of a shallow, storm-dominated shelf (Picard \& Uygur, 1982; Lord, 1985), suggesting further upward-deepening shoreface environments. 
The Thalassinoides assemblage recurs and is observed in micritic sandstone and sandy allochemic limestone facies, documenting intense bioturbation at the sediment-sediment interface. This sandy allochemic limestone is thickly bedded and consists mainly of Thalassinoides horizontalis and T. paradoxicus. Intense bioturbation and the appreciable amount of siliciclastic-bioclastic material suggest that deposition took place in a lower shoreface environment (Joseph \& Patel, 2015). Moreover, Thalassinoides burrows are frequently related to oxygenated settings and soft, yet fairly cohesive, substrates indicate a lower shoreface environment (Bromley \& Frey, 1974; Kern \& Warme, 1974).

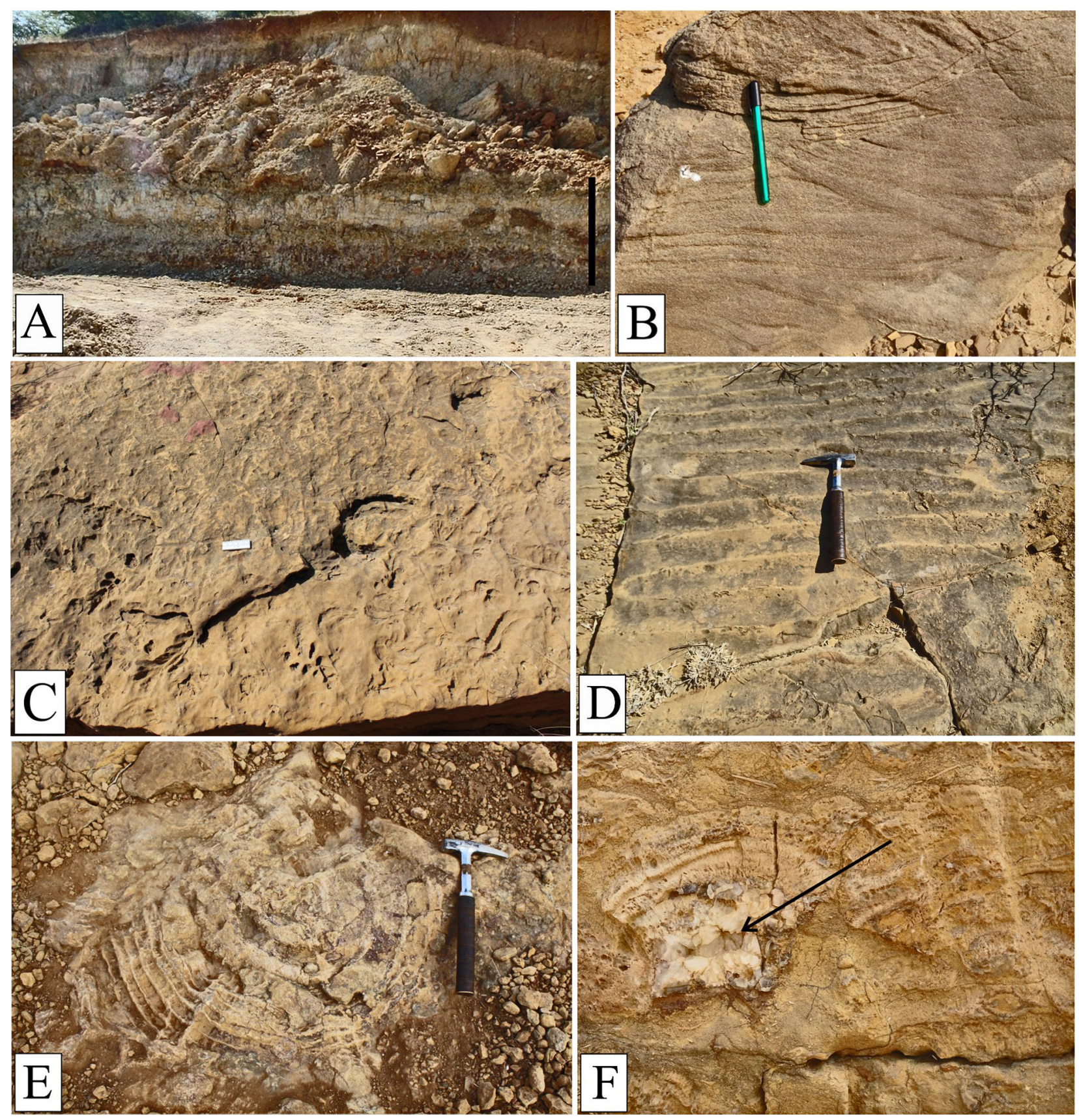

Fig. 3. A - Argillaceous shale, the oldest rock unit exposed in the core of the Chorar dome (scale bar equals 5 feet); B Planar-trough, cross-bedded micritic sandstone facies marking a change in sediment influx towards the upper part of the Hadibhadang Shale Member; C - Hillichnus- bearing sandy allochemic limestone developed at the base of the Hadibhadang Sandstone Member, marking the onset of TST-II; D - Ripples in sandy allochemic limestone; E - Top view of large, well-preserved, in-situ coral on the bedding surface of coralline limestone at the close of TST-II; F Vertical view of an in-situ coral skeleton with recrystallised large calcite crystals (arrow) 
The sandy allochemic limestone of TST-I contains a variable amount of micrite and allochems with horizontal biogenic structures. These pieces of evidence indicate fluctuations of energy conditions and bathymetry in a shoreface environment, suggesting an increase in accommodation space form- ing aggradational deposits in a synrift basin margin succession.

The thickly bedded sandy allochemic limestone is overlain by the coralline limestone facies $(2.7 \mathrm{~m})$ that marks the top of TST-I. This facies is characterised by corals of large diameters (Fig. 3E, F) which
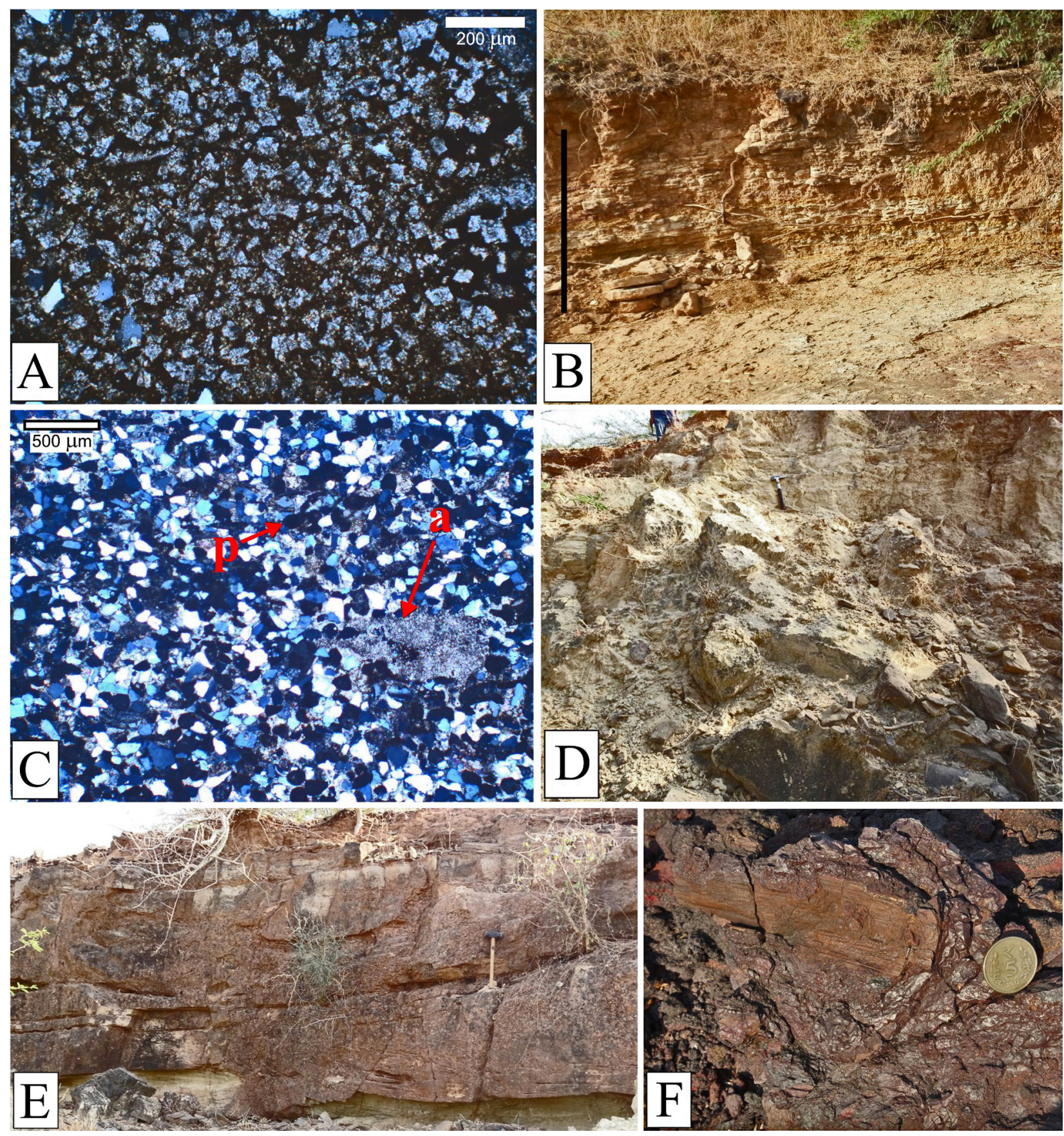

Fig. 4. A - Photomicrograph showing dolomite crystals in the coralline limestone facies at the top of the Hadibhadang Sandstone Member; B - Thinly bedded mudstone marking the flooding surface and onset of RST-II in the Ratanpur Sandstone Member (scale bar equals $150 \mathrm{~cm}$ ); C - Photomicrograph of allochemic sandstone consisting predominantly of quartz along with allochems such as pellets (p) and algae (a), indicating a change in clastic influx; D - Aggrading, thickly bedded, cross-bedded white sandstone; E - Ferruginous sandstone facies containing fossilwood (F) of the Ratanpur Sandstone Member, marking the fall of base level 
are sparitised and dolomitised (Fig. 4 A) with allochems including algae and shell fragments. The absence of primary sedimentary structures and well-developed corals with a negligible amount of clastic sediments suggest offshore environment. The coralline limestone that is overlain by thinly bedded mudstone facies (Fig. 4 B), intercalated with shales, representing calm and oxygenated offshore conditions, suggest a maximum sea level rise during the late Bathonian, marking the Flooding Surface (FS) that also coincides (Fig. 5) with the global sea level rise (Haq et al., 1988; Haq \& Al-Qahtani, 2005). Thus, the TST-I represents aggradational deposits in a middle shoreface to offshore environment.

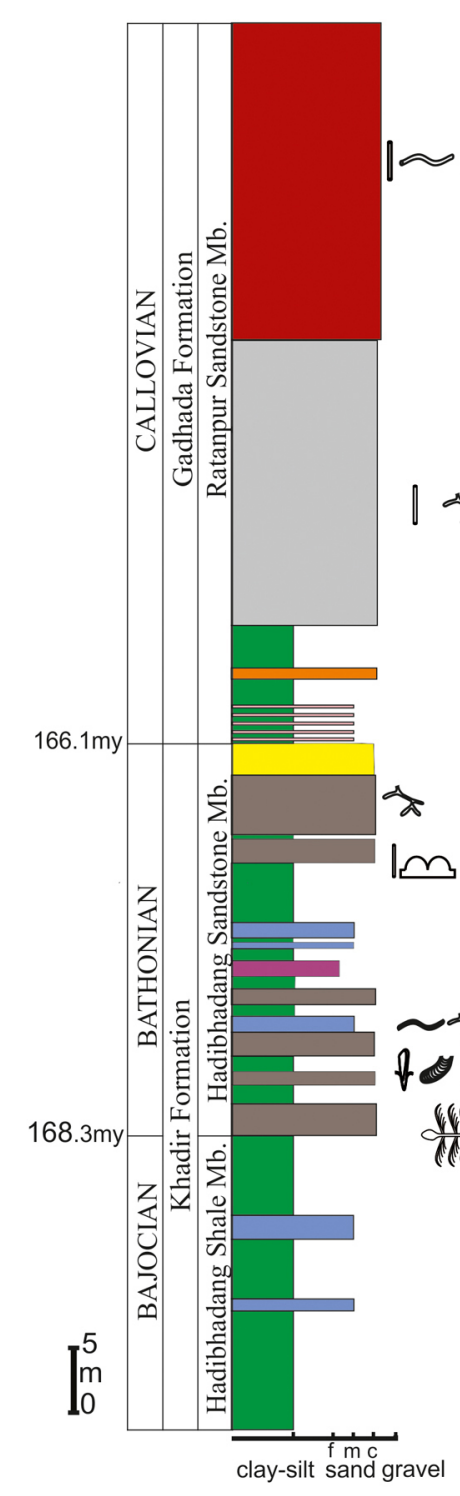

\subsubsection{Highstand Systems Tract (HST)-II}

HST-II is represented by a 55-m-thick succession of the Ratanpur Sandstone Member of the Gadhada Formation, of Callovian age. It comprises mudstone facies intercalated with argillaceous shale which is overlain by the allochemic sandstone facies, which in turn is overlain by the cross-bedded white sandstone and ferruginous sandstone facies of lower and middle shoreface environments, respectively.

The mudstone facies (Fig. 4B) is characterised by thinly bedded lime/carbonate mud, intercalated with shales, which indicate calm conditions of lower shoreface-offshore environments. The basal fine-grained succession that overlies the flooding surface indicates the onset of a progradational coast-

Global sea level curve

(Haq \& Al Qahtani, 2005)

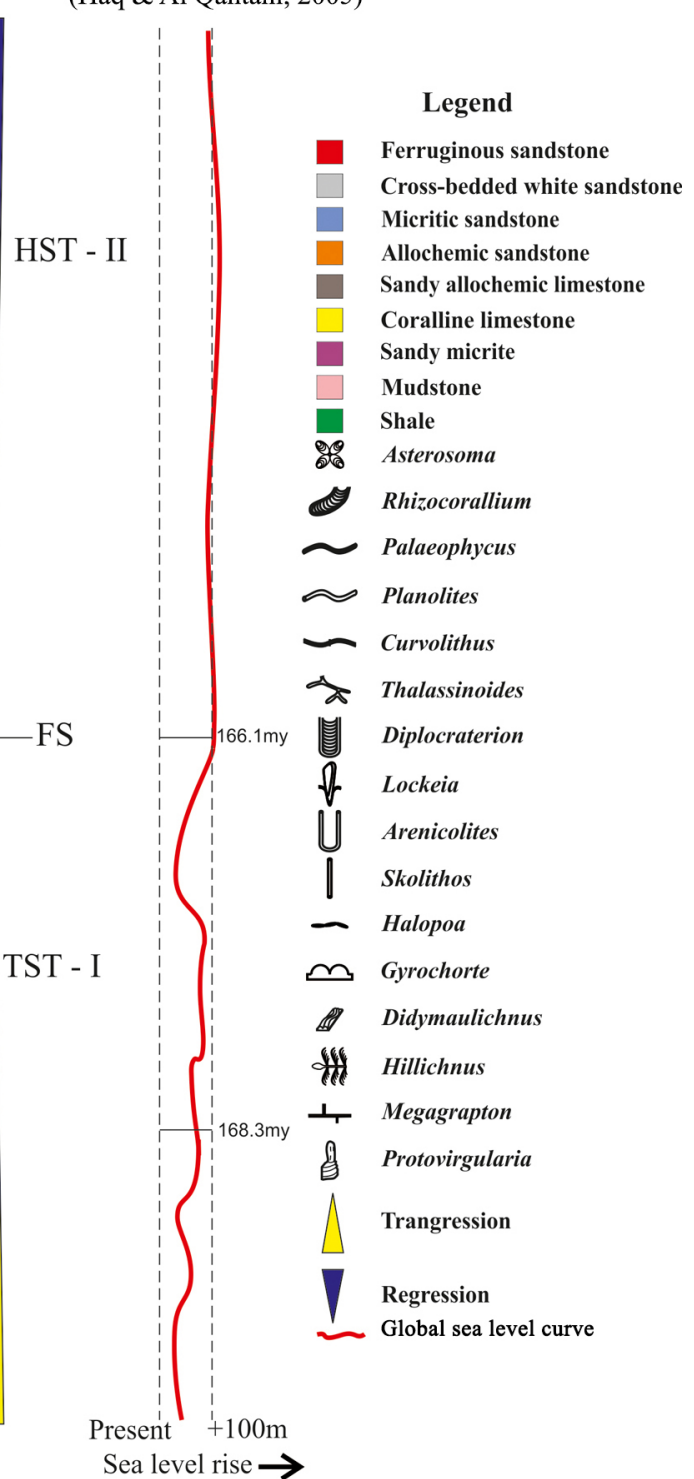

Fig. 5. Composite litholog of the Middle Jurassic succession of Chorar Island, showing representative facies and associated ichnofossil genera within each genetic cycle and corresponding to global sea level curve 
line (Martins-Neto \& Catuneanu, 2009), overlain by allochemic sandstone. This allochemic sandstone contains $\sim 60$ per cent of siliciclastic component with abundant pellets (Fig. 4C), suggesting an increase in clastic sediment supply in a tidally influenced shoreface zone and a reduction of accommodation space during the early Callovian and marking the beginning of HST-II (Fig. 5).

The allochemic sandstone facies is overlain by thick, friable, poorly sorted and bioturbated, cross-bedded white sandstone facies (Fig. 4D), which in turn is overlain by the cross-bedded ferruginous sandstone (Fig. 4E) facies that yields body fossils such as bivalves, gastropods, as well as driftwood (Fig. 4F) which are bioturbated at varying intensities. The predominance of vertical burrows (Arenicolites, Diplocraterion and Skolithos) in the Skolithos assemblage belonging to the Skolithos Ichnofacies (Seilacher, 1967) and indicating moderate to high-energy conditions in the middle shoreface (Pemberton et al., 2001).

The deposits of HST-II show a shallowing-upward sequence of lower- and middle shoreface environments, indicating a sea level drop during the Callovian. The intercalated sequence of mudstone and allochemic sandstone facies marks the onset of progradation, while the thick, cross-bedded, white and ferruginous sandstone facies and the associated trace fossils mark a drop in base-level during the Callovian. The HST-II represents a major progradation of the shoreline in the Chorar Island area during the Callovian, which does not coincide with the global sea level curve (Haq et al., 1988; Haq \& Al-Qahtani, 2005). The development of a HST due to sediment supply that outpaced the accommodation space in a rift environment has been observed in the Gainsborough Trough (UK) in upper Namurian strata (Church \& Gawthorpe, 1997). Hence, HST-II indicates a continuous creation of accommodation space within a synrift basin margin compensated by sediment supply outpacing the accommodation space and resulting in an aggrading thick clastic sequence (Fig. 5).

\section{Conclusions}

Our sedimentological and ichnological analysis of Chorar Island, the easternmost part of the Kachchh Basin which characteristically comprises shallow-marine synrift sediments of Middle Jurassic age, allows the following conclusions to be drawn.

Chorar Island (Kachchh Basin) comprises a 109-m-thick Bajocian-Callovian succession that is characterised by bioturbated clastic, non-clastic and mixed siliciclastic-carbonate sedimentary rocks of shoreface-offshore environments. Sixteen ichnogenera document five ichnoassemblages that are represented by the Skolithos (Skolithos assemblage) and Cruziana (Gyrochorte, Hillichnus, Rhizocorallium and Thalassinoides assemblages) ichnofacies. Sedimentological and ichnological evidence has revealed two genetic cycles: TST-I and HST-II, separated by Flooding Surface (FS).

The Middle Jurassic synrift basin margin succession of Chorar Island displays two Genetic Cycles; TST-I marks a sea level rise during the Bajocian-Bathonian that matches the short-term global eustatic sea level curve, while HST-II (Callovian) represents a deviation from the global sea level curve due to abundant sediment supply that outpaced accommodation space.

\section{Acknowledgements}

The authors are grateful to the Head of the Department of Geology, for providing the necessary facilities to carry out the present research work.

\section{References}

Biswas, S.K., 1971. Notes on the geology of Kutch. The Quarterly Journal of the Geological, Mining, and Metallurgical Society of India 43, 223-236.

Biswas, S.K., 1977. Mesozoic rock-stratigraphy of Kutch, Gujarat. The Quarterly Journal of the Geological, Mining, and Metallurgical Society of India 49, 1-52.

Biswas, S.K., 1983. Cretaceous of Kutch-Kathiawar region. [In:] Proceeding of Symposium on Cretaceous of India Palaeoecology, Palaeogeography and Time boundaries, Indian Association of Palynostratigraphers 40-65.

Biswas, S.K., 1993. Geology of Kutch. KD Malaviya Institute of Petroleum Exploration, Dehradun, 450 pp.

Biswas, S.K., 1999. A review on the evolution of rift basins in India during Gondwana with special reference to western Indian basins and their hydrocarbon prospects. [In:] Proceedings of Indian National Science Academy part A 65, 261-283.

Biswas, S.K., 2005. A review of structure and tectonics of Kutch basin, western India, with special reference to earthquakes. Special section: Intraplate Seismicity. Current Science 88, 1592-1600.

Biswas, S.K., 2016. Mesozoic and Tertiary Stratigraphy of Kutch (Kachchh) - A review. Special Publication of Geological Society of India 6, 1-24.

Bromley, R.G. \& Frey, R.W., 1974. Redescription of the trace fossil Gyrolithes and taxonomic evaluation of Thalassinoides, Ophiomorpha, and Spongeliomorpha. Bulletin Geological Society of Denmark 23, 311-335.

Bromley, R.G., Uchman, A., Gregory M.R. \& Martin, A.J., 2003. Hillichnus lobosensis igen. et isp. nov., a complex 
trace fossil produced by tellinacean bivalves, Paleocene, Monterey, California, USA. Palaeogeography, Palaeoclimatology, Palaeoecology 192,157-186.

Carmona, N.B., Mángano, M.G., Buatois, L.A. \& Ponce, J.J., 2010. Taphonomy and paleoecology of the bivalve trace fossil Protovirgularia in deltaic heterolithic facies of the Miocene Chenque Formation, Patagonia, Argentina. Journal of Paleontology 84, 730-738.

Catuneanu, O., 2006. Principles of Sequence Stratigraphy. Elsevier, Amsterdam, 386 pp.

Catuneanu, O., Abreu, V., Bhattacharya, J.P., Blum, M.D., Dalrymple, R.W., Eriksson, P.G., Fielding, C.R., Fisher, W.L., Galloway, W.E., Gibling, M.R., Giles, K.A., Holbrook, J.M., Jordan, R., Kendall, C.G., St, C., Macurda, B., Martinsen, O.J., Miall, A.D., Neal, J.E., Nummedal, D., Pomar, L., Posamentier, H.W., Pratt, B.R., Sarg, J.F., Shanley, K.W., Steel, R.J., Strasser, A., Tucker, M.E. \& Winker, C., 2009. Towards the standardization of sequence stratigraphy. Earth Science Review 92, 1-33.

Chamberlain, C.K., 1977. Ordovician and Devonian trace fossils from Nevada: Nevada Bureau of Mines and Geology, Bulletin 90, 24 pp.

Church, K.D. \& Gawthorpe, R.L., 1997. Sediment supply as a control on the variability of sequences: an example from the late Namurian of northern England. Journal of the Geological Society, London 54, 55-60.

Darngawn, J.L., Patel, S.J., Joseph, J.K., \& Shitole, A.D., 2018. Palaeoecological significance of trace fossils of Chorar Island, Eastern Kachchh Basin, Western India. Journal of the Palaeontological Society of India 63, 169-180.

Dunham, R.J., 1962. Classification of carbonate rocks according to depositional textures. [In:] Ham, W.E. (Ed.): Classification of Carbonate Rocks. American Association Petroleum Geology, Memoirs 1, 108-121.

Ekdale, E.G. \& Ekdale, A.A., 2018. Hillichnus lobosensis, an unusually complex trace fossil of burrowing bivalves from the Paleogene of southern California, USA. Palaeogeography, Palaeoclimatology, Palaeoecology 493, 119-125.

Fürsich F.T., 1998. Environmental distribution of trace fossils in the Jurassic of Kachchh (Western India). Facies 39, 243-272.

Fürsich, F.T., Alberti, M. \& Pandey, D.K., 2013. Stratigraphy and paleoenvironments of Jurassic rocks of Kachchh: Field Guide. Special Issue, Beringeria 7, 174 pp.

Fürsich, F.T., Pandey, D.K., Callomon, J.H., Jaitly, A.K. \& Singh, I.B., 2001. Marker beds in the Jurassic of the Kachchh Basin, Western India: their depositional environment and sequence stratigraphic significance. Journal Palaeontological Society of India 46, 173-198.

Galloway, W.E., 1989. Genetic stratigraphic sequences in basin analysis, I. Architecture and genesis of flooding-surface bounded depositional units. American Association of Petroleum Geologists Bulletin 73, 125-142.

Gibert, J.M.D. \& Benner, J.S., 2002. The trace fossil Gyrochorte: ethology and paleoecology. Revista Espanola de Paleontologia 17, 1-12.
Guha, D.K., 1977. On some Mesozoic Ostracoda from subcrops of Banni, Rann of Kutch, India. [In:] M.S. Srinivasan (Ed.): Proceeding of the 6th Indian Indian Colloquium on Micropaleontology \& Stratigraphy, Banaras 84-90.

Hakes, W.G., 1985. Trace fossils in brackish-marine shales, Upper Pennsylvanian of Kansas, U.S.A. [In:] Curran, H.A. (Ed.): Biogenic Structures: Their Use in Interpreting Depositional Environments. Society of Economic Paleontologists and Mineralogists, Special Publication 35, 21-35.

Haq, B.U. \& Al-Qahtani, A.M., 2005. Phanerozoic cycles of sea-level change on the Arabian Platform. GeoArabia 10, 127-160.

Haq, B.U., Hardenbol, J. \& Vail, P.R., 1988. Mesozoic and Cenozoic chronostratigraphy and eustatic cycles. [In:] Wilgus, C.K., et al. (Eds): Sea-level research: An integrated approach. Society of Economic Paleontologists and Mineralogists Special Publication 42, 71-108.

Howard, J.D. \& Singh, I.B., 1985. Trace fossils in the Mesozoic sediments, Kachchh, Western India. Palaeogeography, Palaeoclimatology, Palaeoecology 5, 99-122.

Joseph, J.K. \& Patel, S.J., 2015. Ichnology of mixed siliciclastic-carbonate sedimentary cycles and their sequence stratigraphic context: Kaladongar Formation (Middle Jurassic) of Kachchh, western India. Volumina Jurassica 13, 81-100.

Joseph J.K., Patel S.J. \& Bhatt, N.Y., 2012a. Trace fossil assemblages in mixed siliciclastic-carbonate sediments of the Kaladongar Formation (Middle Jurassic), Patcham Island, Kachchh, Western India. Journal of Geological Society of India 80, 189-214.

Joseph, J.K., Patel, S.J. \& Bhatt, N.Y., 2012b. Sedimentology and Depositional environments of the Kaladongar Formation (Middle Jurassic), Patcham Island, Kachchh, Western India. Gondwana Geological Magazine spec. vol. 13, 75-86.

Kern, J.P.H. \& Warme, J.E., 1974. Trace fossils and bathymetry of the Upper Cretaceous Point Loma Formation, San Diego, California. Geological Society of America Bulletin 85, 893-900.

Khosla, S.C., Jakhar, S.R., Nagori, M.L., Felix, A.D. \& Kumari, M., 2003. Jurassic Ostracode Fauna from the Type Section of Khadir Formation, Kachchh and Lophocythere vertipolycostata n. sp. Journal Geological Society of India 61, 61-74.

Knaust, D., 2013. The ichnogenus Rhizocorallium: classification, trace makers, palaeoenvironments and evolution. Earth Science Review 126, 1-47.

Kulkarni, K.G. \& Ghare, M.A., 1991. Locomotory traces (Repichnia) from the Jurassic sequence of Kutch, Gujarat. Journal of the Geological Society of India 37, 374.

Lord, G.D., 1985. Stratigraphy, petrography and depositional environments of the Twin Creek Limestone - Arapien Shale, northern and central Utah. Unpublished. University of Utah, $87 \mathrm{pp}$.

Martins-Neto, M.A. \& Catuneanu, O., 2009. Rift sequence stratigraphy. Marine and Petroleum Geology 27, 247253. 
Myrow, P.M., 1995. Thalassinoides and the Enigma of Early Paleozoic open-framework burrow systems. Palaios $10,58-74$.

Osgood, R.G.Jr., 1970. Trace fossils of the Cincinnati area. Palaeontographica Americana 6, 277-444.

Patel, S.J. \& Joseph, J.K., 2012. Deepening upward sequence of Callovian-Oxfordian Gangta Bet, Wagad, Eastern Kachchh, India. Proceeding of Annual International Conference on Geological and Earth Science, 13-18.

Patel, S.J., Desai, B.G. \& Shukla, R., 2009. Paleoecological significance of the trace fossils of Dhosa Oolite Member (Jumara Formation), Jhura Dome, Mainland Kachchh, Western India. Journal of Geological Society of India 74, 60-614.

Patel, S.J., Joseph, J.K. \& Bhatt, N.Y., 2010. Sequence stratigraphic significance of sedimentary cycles and trace fossils in the Middle Jurassic rocks of Kuar Bet area, Patcham Island, Kachchh, Western India. Special Publication of Gondwana Geological Magazine 12, 189-97.

Patel, S.J., Joseph, J.K. \& Bhatt, N.Y., 2013. Sequence stratigraphic analysis of the mixed siliciclastic-carbonate sediments (Middle Jurassic) of the Patcham Island, Kachchh, Western India: An ichnological approach. Special Publication of Geological Society of India 84-111.

Patel, S.J., Joseph, J.K. \& Bhatt, N.Y., 2014. Ichnology of the Goradongar Formation, Goradongar Hill Range, Patcham Island, Kachchh, Western India. Journal of Geological Society of India 84, 129-154.

Patel, S.J., Darngawn, J.L., Joseph, J.K. \& Shitole, A.D., 2018., Stratigraphy and Sedimentology of Middle Jurassic Sequence of Chorar Island, Patan District, Kachchh Basin, Gujarat. Journal Geological Society of India 92, 419-426.

Patel, S.J., Desai, B.G., Vaidya, A.D. \& Shukla, R., 2008. Middle Jurassic trace fossils from Habo Dome, Mainland Kachchh, Western India. Journal of Geological Society of India 71, 345-362.

Pemberton, S.G., 2001. Ichnology and sedimentology of shallow to marginal marine systems. Geological Association of Canada. Short Course 15, pp. 343.

Pemberton, S.G. \& MacEachern, J.A., 1995. The sequence stratigraphic significance of trace fossils: examples from the Cretaceous foreland basin of Alberta, Canada. [In:] J.C. Van Wagoner \& G. Bertram (Eds): Se- quence Stratigraphy of Foreland Basin Deposits: Outcrop and Subsurface Examples from the Cretaceous of North America, American Association of Petroleum Geologists, Memoir 64, 429-475.

Pemberton, S.G., Spila, M., Pulham, A.J., Saunders, T., Maceachern, J.A., Robbins, D. \& Sinclair, I.K., 2001. Ichnology and sedimentology of shallow to marginal marine systems: Ben Nevis and Avalon Reservoirs, Jeanne d'Arc Basin. Geological Association of Canada, Short Course Notes 15, 353.

Picard, M.D. \& Uygur, K., 1982. Mixed terrigenous-carbonate rocks in Jurassic Arapien Shale of central Utah. [In:] D.L. Nielson (Ed.): Overthrust belt of Utah. Utah Geological Association 10, 181-198.

Ruban, D.A., 2015. Mesozoic long-term eustatic cycles and their uncertain hierarchy. Geoscience Frontiers 6, 503-511.

Savrda, C.E. \& Bottjer, D.J., 1986. Trace-fossil model for reconstruction of paleo-oxygenation in bottom waters. Geology 15, 3-6.

Seilacher, A., 1953. Studien zur Palichnologie II. Die fossilen Ruhespuren (Cubichnia). Neues Jahrbuch für Geologie und Paläontologie, Abhandlungen. 98, 87-124.

Seilacher, A., 1967. Bathymetry of trace fossils. Marine Geology 5, 413-428.

Seilacher, A., 2007. Trace Fossil Analysis. Springer, Berlin, 226 pp.

Shringarpure, D.M., 1986. Trace fossils at omission surface from Mesozoic of Kutch, Gujarat, Western India. Bulletin of the Geological, Mining and Metallurgical Society of India 54, 13-148.

Vail, P.R., Audemard, F., Bowman, S.A., Eisner, P.N. \& Perez-Cruz, C., 1991.The stratigraphic signatures of tectonics, eustasy and sedimentology - an overview. [In:] G. Einsele, W. Ricken \& A. Seilacher (Eds): Cycles and Events in Stratigraphy, Springer-Verlag, Berlin, pp. 617-659.

Worsley, D. \& Mørk, A., 2001. The environmental significance of the trace fossil Rhizocorallium jenense in the Lower Triassic of western Spitsbergen. Polar Research 20, 37-48.

Manuscript received: 27 July 2018 Revision accepted: 28 February 2019 